\title{
Local wisdom regarding coastal resource management among a fishermen community in Youtefa Bay, Papua.
}

\author{
Akhmad Kadir ${ }^{*}$, Agustina Ivonne Poli ${ }^{2}$, Pawennari Hijjang ${ }^{3}$, Usman Idris ${ }^{4}$, \\ Aisyah Ali ${ }^{5}$, Fredrik Sokoy ${ }^{6}$
}

\author{
1 Universitas Cenderawasih, Papua, Indonesia. \\ 2 Universitas Cenderawasih, Papua, Indonesia. \\ 3 Universitas Hasanuddin, Makassar, Indonesia. \\ 4 Universitas Cenderawasih, Papua, Indonesia. \\ 5 Universitas Cenderawasih, Papua, Indonesia. \\ ${ }_{5}^{5}$ Universitas Cenderawasih, Papua, Indonesia.
}

*Correspondence author: qiatri_akhmad@yahoo.com

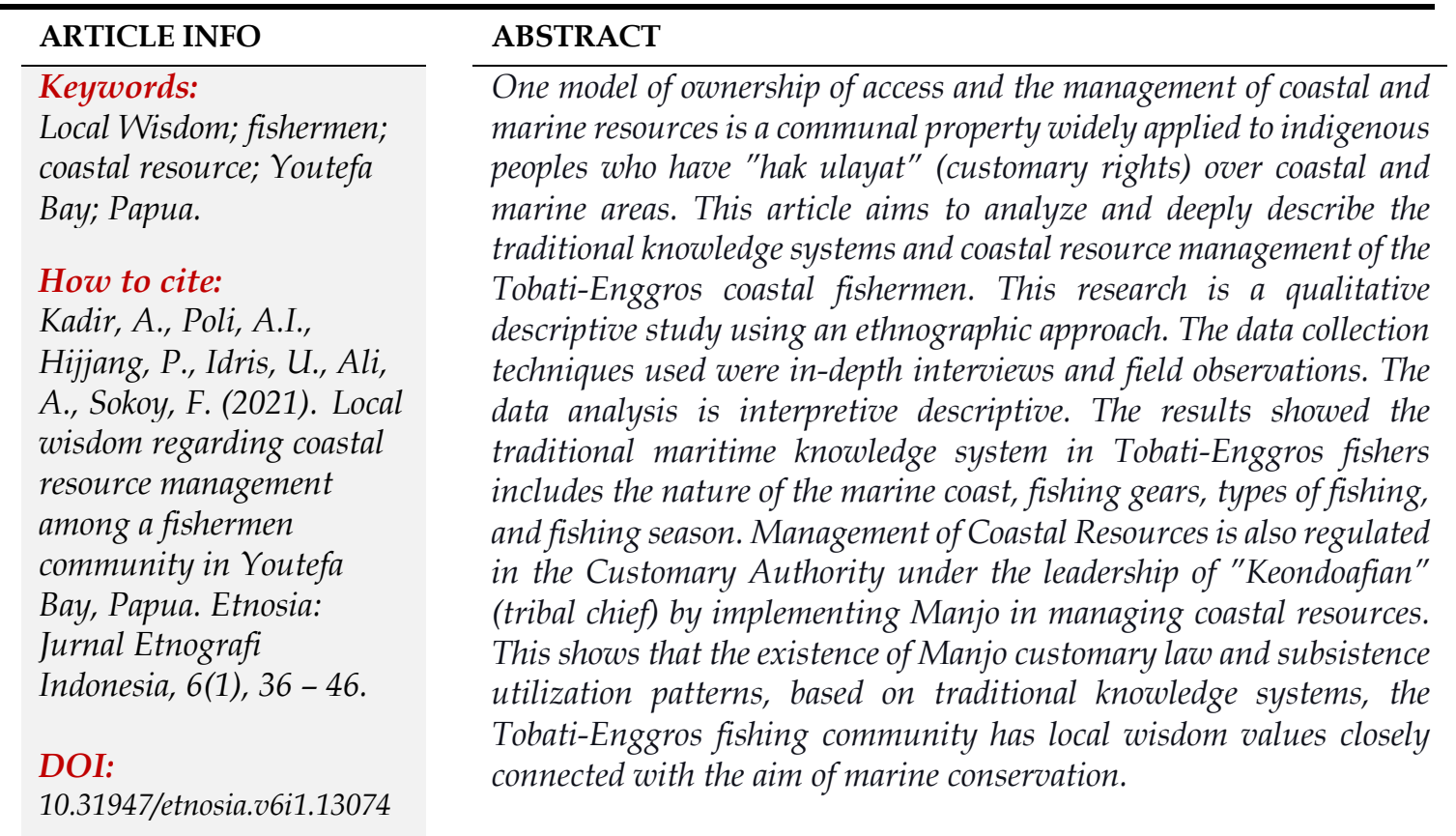

\section{Introduction}

Humans are always developing adaptation patterns to the environment in which they live in order to ensure their survival. This is a step towards survival, so that managing the level of availability of resources becomes the basis for the livelihood system (Purwanto, 2010). One of the characteristics of a simple, subsistence society is the use of available resources only to make ends meet. Then, related to ownership or access to resources, it is communal and managed together through certain institutions. In fishing communities whose daily activities interact with the marine environment, there are 
efforts to adapt to their environment which result in behavior patterns to manage and utilize resources to meet their daily needs. Fishing communities have a different cultural style from other communities as a result of their interaction with the environment along with the resources that are in it. These cultural patterns become a frame of mind or a reference for the behavior of the fishing community in living their daily lives (Kusnadi, 2005).

Various coastal ethnic groups in the eastern archipelago apply the sasi method (a customary law method) as a dialectical process from the adaptation of culture to the environment in order to utilize, maintain and care for the level of availability of coastal and marine natural resources. This is a management pattern with communal property rights where the resource is controlled by a clearly identified user community, ownership based on customary rights which is regulated by a system of customary norms and laws (Berkes, 1989; Feeny, 1994). For example, in southeast Maluku, the Kei people practice sasi known as Hawear Bahwaren to sasi land and sea areas which are the customary rights of the Kei people whose mechanisms are regulated in the customary law of larvul Ngabal (Lontor, et al, 2016). Furthermore, in the Sentani people there is Puyakhabhu as the basis of values and norms in managing and utilizing marine resources in Lake Sentani (Hijjang, et al, 2018). Then, on the peninsula of the north coast of Papua in the Bay of Depapre the Tefra people apply the Tiatiki Sasi, to regulate the Depapre bay area which is their customary land area, according to Taryono, et al. (2018), this is a local community institution that can support the conservation of coastal and marine resources in Depapre Bay. All these ethnic groups, according to Hijjang (2016), by implementing sasi as well as a mechanism for preserving resources, which is a form of local wisdom in managing the environment, there are limitations on exploitation and exploration of resources that aim to regenerate and ensure the level of availability so as to reduce overfishing activities, which in turn will maintain the balance of the ecosystem and secure the sustainability of the fulfillment of human life needs in the future that is in line with the paradigm of sustainable development.

The management of marine, coastal and marine resources that implements sasi from some of the exemplary ethnic groups is classified as a communalism paradigm management pattern. As stated by Lampe (2012) that the communalism paradigm describes the characteristics of the relationship of togetherness or the unity of fishing communities with their marine environment, balance relations, human-environmental intersubjective relationships, marine resources are understood as gifts from nature, for that reciprocally, humans must also maintain nature, so that there is equiblirium in the ecosystem. The existence of traditional rules / norms as a reference for decisions and actions illustrates that the communalism paradigm also describes the characteristics of a subsistence fishing community economic system with simple, environmentally wise technology. For example, the Bajo Takabonerate fishermen, through the Panglima Menteng institutional system, were very strict to limit access in the management and utilization of marine resources in the past (Lampe, 2012).

The Tobati-Enggros Fishermen Community in Youtefa Bay, Jayapura City, is one of the fishermen groups that also applies sasi in the process of exploiting and managing coastal resources in Youtefa Bay, which is also a customary area. The sasi system in the Tobati 
Enggros fishing community is manjo (Wanggay, 2011; Tebaiy, et al, 2017). Although there have been previous researchers who have conducted studies on the same topic, namely Wanggay (2011), Tebaiy, et al (2015), Abidin (2017), all of them have not studied from an anthropological perspective. The Wanggay study (2011) is the first to discuss Manjo as a set of norm systems that serve as a reference in regulating, exploiting, and managing coastal and marine resources. Meanwhile, Tebaiy, et al. (2015) see Manjo as a customary law which applies the principles of resource management aimed at conservation and sustainable resources for the future. Then, Abidin (2017) who sees coastal resource management in the Tobati Enggros fishing community as an activity to meet needs that are dissected based on the Maaqasid Syariah approach in sharia economic studies. In contrast to previous studies, this article specifically describes, first, the traditional knowledge system of the Tobati-Enggros coastal fishermen regarding maritime knowledge related to the management of coastal resources in Youtefa Bay. Second, the explanation of Manjo customary law as a system of traditional norms in the management of coastal resources as well as cases of violations and sanctions given and sasi hor as a mechanism for maintaining resources.

\section{Method}

This research is a type of qualitative research using an ethnographic approach. This study aims to explore the point of view of the Tobati-Enggros indigenous community related to local knowledge systems and patterns of coastal resource management in Youtefa Bay, and their practices. The data collection techniques used were in-depth interviews, observations, and FGD (Focus Group Discussion). Interview techniques were used to collect data on the local knowledge system of the Tobati-Enggros community, especially knowledge about coastal and marine nature, traditional technology, and bay water resources. Afterwards, observation is used to observe patterns of utilization and management of coastal resources in the Tobati-Enggros community. Then, the research instruments used were open structured interview guidelines, voice and image recording devices, and filednotes as a reflection aid in the field.

The informant tracing technique used is Snowball by assigning one key informant, and involving a Guide. The informants involved in this study consisted of customary leaders (ondoafi), tribal heads, clan heads, and fishermen in the Bay, as well as teteh-teteh (traditional leaders) of Tobati-Enggros. During the field data collection process, we adjusted the informants' busyness to the time of our arrival to conduct the interview so as not to interfere with their daily activities. For this reason, before starting field data collection, we first asked about the readiness and willingness of our prospective informants. The data analysis technique used in this study refers to those described by Creswell (2012) which uses 5 steps, namely: Processing and preparing data for analysis, Reading the entire data, Analyzing in more detail by coding the data. Apply a coding process to describe settings, people, categories and themes. Then, describe the themes in the form of descriptive-interpretive narratives. 


\section{Result and discussion}

The Tobati-Enggros Fishermen Community is classified as an indigenous ethnic group in the Youtefa Bay which is included in the Mamta or Tabi customary area (Cowan, 1953; Erari, 1999; Purba, Mansoben, 1994; 2002, Kadir, 2017), who are also the Jayapura City's Indigenous Ethnic groups who inhabit the Youtefa Bay area, which is a bay inside the bay of Yos Sudarso. The Tobati people have long lived in Youtefa Bay, the Youtefa bay which is based on mythology where they came from. The Tobati people call the bay as the bay of iria, as the original bay of the Tobati. The name that is better known today, is Youtefa, which is a term that comes from the Tabla people, which means a large village on the eastern horizon, in a village founded by the Tobati people consisting of 12 clans, namely Hamadi, Iruw, Meraudje, Dawir, Hababuk, Hassor, Mano, Haai, Hababuk, Hitar, Srem-srem, Iwo. The village of the Tobati people used to be only one, but due to the increasing population, a second village was formed which was called the Enggros village, for this reason, the terminology used in this study is Tobati-Enggros to cover the Tobati people in the two villages. The Tobati-Enggros Fishermen Community has the customary rights of Youtefa Bay and the surrounding coastal areas. The Tobati-Enggros Fishermen Community includes a coastal fishing group of small boats users or traditional boats that use oars and sail around the Youtefa Bay to the edge of the Pacific Ocean (Jakarimilena, 1993). In the context of the management and utilization of coastal resources in the bay area, the Tobati Enggros Fishermen community has customary laws to enforce the bay area known as Manjo. The discussion focuses on exploring the knowledge system and management of coastal resources in Tobati-Enggros fishermen.

\section{- Tobati-Enggros Fisherman Knowledge System}

Tobati-Enggros fishermen as traditional fishermen have a set of knowledge obtained from the results of enculturation and their life experiences as coastal fishermen. As stated by Liliweri (2002: 222-223), traditional knowledge is a cumulative body of knowledge about "what is known and how to know" from a group of people about their world. From this knowledge building system, there is a universal classification of objects, activities, events that form a culture. The knowledge system is shared and transmitted across generations, both through oral and written traditions. This set of knowledge is also dynamic, based on the results of environmental dialectics and internal creativity and external influences which can open up the possibility for modification and adjustment to the existing order to meet the needs of life in various emerging economic activities (Hijjang \& Lampe, 2017; Kadir, et al, 2020). There are 5 characteristics of local wisdom possessed by local communities, namely localization, resource control, respect for nature, resilience and flexibility, and social responsibility (Liliweri, 2000: 225-226). In order to explore the local wisdom of the Tobati Engross fishing community based on the 5 characteristics of local wisdom, therefore the local knowledge of Tobati Enggros fishermen related to their daily activities and the surrounding environment will be described.

\section{- Knowledge about the environment}

The Tobati Enggros Fishermen Community has strong ties to Youtefa Bay, because it is closely related to the mythology of their origins. One of the developed 
mythology is that the origin of the Tobati people came from the sky, the god of the sun who was called Tab came down to earth and created Iria which means a very beautiful place as the place of the origin Tobati people and the first humans, at this time Iria means Youtefa bay (Al-Makassary, 2017). Thus, based on the mythology, Youtefa bay is intended for the Tobati people, because the Tobati people were first created by Tab (the god of the sun) in that place. Youtefa Bay is closely related to the Tobati people and to the origins of the Tobati Enggros, which shows that the TobatiEnggros people and their environment have become an integral part of a psychomonumentive ecosystem that is the natural surroundings are regarded as dignity, inheritance and a family monument, so that no one else should interfere. This view reflects the existence of a strong psychological tie to locations that are considered as historical places at the time of their migration / mobility, or the origins where their ancestors first lived, then spread and are now permanently located in existing settlements (Frank, et al, 2020).

The myths that live and are believed by members of the fishing community become a pattern of their actions in interpreting things (Akhmad, et al, 2018), especially in this context, namely the environment of the bay, coast, and the surrounding land. At this stage, humans find their identity. Humans are surrounded by the universe so that humans are easily entered by natural forces and power. Humans are still open and thus participate with the forces of nature which make them aware that there are magical powers that are mystical. However, humans are still unable to perceive objects or reality with their senses so that humans and nature become one, then giving birth to an identity from the combination of humans and their natural surroundings which is formed through the myth of origin (Idris, 2017; Akhmad, et al, 2019).

Thus fishermen begin to adapt to the environment and with this adjustment process fishermen develop cultural patterns to manage the coastal environment to meet their daily needs and survival (Naping, 2017). The adaptation pattern developed is an adjustment to the type and level of resource availability that can be managed and utilized in the surrounding environment.

\section{- Knowledge of fishing gear}

Tobati-Enggros fishermen catch fish in the bay and outside the bay, where the boundaries of the fishing area are regulated by customary law. Enggros fishermen, for example, are not allowed to catch fish in the Tobati sea area and vice versa, without the permission of Kharsori (Wanggay, 2011; Tebay, 2015). Fishing activities are carried out in several ways; nets, fishing, diving, and fish bombs (the result of a new innovation) but it is prohibited by the government because it damages the marine environment ecosystem and destroys fish seeds around the bay. The fishing technology used is a simple tool, namely outrigger boats that use oars as a means of transportation in fishing, the boat is made of wood. Then, the fishing tools used are also simple in the form of gill nets, drag nets, fishing rods, kalawai, mole or spears (fishing gears used by diving and stabbing), sumpil and that was only done around the waters of the Youtefa Bay and does not lead to the high seas, (Abidin, 2017; Tebay, 2013). 
The stages in catching are, first of all, preparing equipment by selecting and sorting out what tools will be used in fishing, the tools used are traditional. This is done to select and sort in the context of finding targets such as the selection of nylon nets and threads it must be separated even though they do not know what to expect at sea but they choose not to use nylon nets if they want to catch crabs. In their selection process, there are many types of nets such as 3-eye, 4-eye nets, Tonda nets, ordinary nets, nylon nets, thread nets, spears, kalawau and they know the places where fish and crabs usually exist. However, the dominant fishing gear used by fishermen is fishing rods whose aim is demersal fish or fish that live near or around the bottom of the waters such as grouper, snapper, stingray and small pelagic fish or fish that live around the water surface such as milkfish, mackerel tuna and mackerel. Another fishing tool is the tuna longline, the target is species such as tuna and skipjack. In addition, there are also circular gill nets for catching small pelagic fish, fixed gill nets for exploiting demersal fish resources, pelagic fishing boat/raft charts, sea cucumber catching slats for catching sea cucumbers, and other traditional fishing tools such as spear forks and spears.

\section{- Knowledge of types of catch}

Catching fish at sea and collecting shellfish are routine jobs carried out by TobatiEnggros fishermen and their main livelihood system throughout the year (Jakarimilena, 1993), although the fishing pattern is carried out periodically alternating between men and women. Catching fish is done by men, the fish which is the catch commodity is small pelagic fish, such as bubarah fish, mackerel fish, estuarine fish, such as milkfish, squid, stingrays, and so on. While the women work to collect their catch in the mangrove forests around their village, the catch of the women is molluscs or shellfish, crabs, and sea cucumbers. The distance covered to reach the fishing grounds in Youtefa Bay ranges from 1-4 miles, while the women catching shellfish is $1-2 \mathrm{~km}$ from their village. The average time spent during the fishing process reaches 1 hour for the fastest, then for the longest fishing time range can reach 8 hours, although the fishing time of 8 hours is relatively dependent on the availability of supplies carried.

\section{- Knowledge of the fishing season}

Knowing two fishing seasons, these two seasons consist of the first six months of the western season (September-February) and the next six months are the eastern season (March-August). The fishing season is based on the monsoon winds that blow from east to west, and vice versa, which is a reference for the rainy and dry seasons. During the dry season, those who carry out fishing activities are adult men in the Tobati Enggros fishing community, the commodities they catch are fish in Youtefa Bay, while in the rainy season adult women will carry out fishing activities. They catch shellfish and crabs in the mangrove forests around Youtefa Bay. This season, men spend their time repairing fishing gear and boats. When they do fishing, fishermen of Tobati-Enggros pay attention to wind conditions, if the wind is too strong, the fishermen will not go fishing because it will affect the condition of the fish, likewise with water that is too tide, because if the water is too tide, the fish will not be as much as when the water starts to recede or commonly known as "meti 
water". At low tide, women also catch shellfish and crabs in mangroves (Abidin, 2017; Jakarimilena, 1993).

\section{- Coastal resource management system in Youtefa Bay}

Based on the mythology of their origin, the Tobati-Enggros people and the Yotefa Bay are a part that is intertwined with one another. Therefore, Yotefa Bay is a customary area which becomes customary rights, which is owned communally. The management of coastal resources in Yotefa Bay is led by Carshori Besar as the highest leader in the customs of the Tobati people based on customary institutions. The indigenous people in Youtefa Bay understand that the waters of Youtefa Bay are owned communally (communal rights) but the right to access the area is regulated by territorial boundaries based on natural signs, namely the peninsula or mountains and the right to use natural resources in Youtefa Bay is also maintained in customary law.

In managing coastal resources, Fishermen Tobati Enggros are familiar with a traditional system of rules known as Manjo (Wanggay, 2011; Tebaiy, et al, 2015). Manjo customary law still exists and applies only to the Tobati and Enggros tribes. Manjo literally consists of two words, "man" refers to custom/law and "jo" refers to village. Therefore, the customary communities in the villages of Tobati and Enggros are regulated by customary law. Violators of customary law will be punished through customary sanctions, ranging from minor violations to serious violations, the punishment is such as destroying fishing gear or the offender being killed by Hobatan (black magic). Local people tend to obey customary law because they believe that unless they get punished for breaking the rules, they will get curses, misfortunes, and even disease from the curse to death. They also have a philosophy that it is "better to die than live without having customs", as is well known by Nekende Pulemiyendebele (Wanggay, 2011; Tebaiy, et al, 2015). The Manjo tradition is traditionally applied as part of the management of marine and coastal resources in the Tobati-Enggros fishermen community. The Manjo tradition, therefore, is the identity of Tobati and Enggros' original knowledge in utilizing and managing marine and coastal resources (Tebaiy, 2015).

Strict rules and sanctions due to the application of Manjo customary law make a significant contribution to conserving natural resources in local communities. The rules in the customary law of Manjo prohibit people from using destructive fishing gear, trawlers, bombs, poisons, and chemicals, because it can damage marine ecosystems and coral reefs. In addition, the prohibition of temporary use of natural resources in certain areas in the villages of Tobati and Enggros and natural resources will be harvested collectively with maximum yields for each household. Manjo's customary law also prohibits local communities from cutting down mangrove forests in coastal areas. This prohibition plays a role in protecting coastal areas from abrasion and erosion. Sanctions on the other hand, will punish anyone who breaks communally agreed rules. The sanctions given to rule breakers depend on the level of violation (Wanggay, 2011; Tebaiy, et al, 2015). Heavy sanctions will be imposed on outsiders who enter the waters without a permit or to anyone using destructive fishing gear as well as on a commercial scale vessel. Heavy sanctions were imposed not only for outsiders but also for local communities in both villages based on their violation of the rules. Sanctions will be given a sound reason, therefore, can be accepted by all local communities based on the 
customary rules made by their anchorors. The sanctions imposed are not new or unintentional but contain the basic values and advice of the attainers. Sanctions can take the form of beatings, destroying fishing gear or confiscating fishing gear. The third form of sanction will be carried out as guarantee or evidence of violation, and this violation will be discussed at the customary council level. The village government as the mediator proposed confiscation of fishing gear at the police station for violating formal legal decisions. In addition, murder is a form of sanction in the past that has been applied to violators of customary territory and is still being carried out today. These sanctions are not directly executed physically, but will be carried out through supernatural powers (Wanggay, 2011; Tebaiy, et al, 2015).

Management of coastal resources based on Manjo customary law is basically a local wisdom that is owned by the Tobati-Enggros fishing community. Local wisdom is a view of life, knowledge or life strategy in the form of activities carried out in answering various problems in fulfilling their needs. The function of local wisdom in the context of conservation and sustainable development is to have the ability to control, as a bulwark to withstand the influence of outside culture, to have the ability to accommodate outside culture, to have the ability to give direction to cultural development, and to have the ability to integrate (Hijjang, 2018; 2016). When humans actualize behavior based on positive experiences in their environment, then humans will be wise in managing an environmentally friendly living system. The values of wisdom in managing natural resources are very important, because empirically one of the most worrying aspects of the crisis phenomenon is when the exploitation of natural resources is not carried out wisely. Therefore, their local knowledge teaches a concept about environmental management wisely so that its use and maintenance is sustainable (Hijjang, 2018; 2016; Karubaha 2007).

Tobati-Enggros fishermen, in terms of management and utilization patterns of marine resources, recognize the customary norm known as Manjo. Manjo is a sasi (customary law) tradition to preserve the coastal marine environment and other land-based resources. With this manjo tradition, the community does not recklessly exploit coastal resources. They carry out a subsistence fishing pattern, some to eat in order to fulfill their daily life, and some of them are sold to get money to fulfill their daily life. This then shows that the existence of Manjo norms as a system of behavior for the Tobati-Enggros people in carrying out their lives as an effort to live in harmony with nature. They take care of each other so that the ecosystem balance and the sufficiency of their lives occur. The utilization of coastal resources with a subsistence pattern is a characteristic of environmentally friendly and sustainable management, especially with the implementation of the sasi system to maintain the life cycle of the functional coastal areas in the context of regeneration and maintaining the availability of resources that are not only intended for the current generation, but also generations to come.

\section{Conclusion}

The relationship between Tobati-Enggros fishermen and their environment, namely Youtefa Bay, shows a mutualist symbiotic relationship to achieve equlibrium in the ecosystem. The construction of the mythology of the Tobati people's attachment to their environment as well as subsistence patterns of use and efforts to always be in harmony 
and adaptive to natural conditions and the surrounding environment is a manifestation of the values of local wisdom that are manifested from the traditional knowledge system in the daily activities of Tobati-Enggros fishermen in fulfilling their daily needs. Although the property is managed communally by the community, but they always want to be in harmony with nature, and look after each other, not trying to conquer them. Thus, this shows that the indigenous Papuans, especially the Tobati-Enggros fishermen community has local wisdom values related to how they see nature and the environment, which then becomes a guideline for them in managing and utilizing resources in a subsistence manner which makes the living environment in Papua maintained in harmony, mutually supporting the sustainability of nature and the sustainability of human life.

\section{Acknowledgments}

This research was funded by a research grant from the Faculty of Social and Political Sciences, Cenderawasih University, Jayapura-Indonesia. This research does not receive specific grants from institutions in the public, commercial, or nonprofit sector.

\section{Conflicts of interest}

Author declares no conflict of interest.

\section{References}

Abidin M. Z. (2017). Pengelolaan Sumber Daya Alam Laut untuk memenuhi kebutuhan Perekonomian Masyarakat Asli Papua dalam kajian Madasid Syariah : Studi Kasus Masyarakat Nelayan Port Numbay Enggros, Jayapura. Tesis. Universitas Islam Negeri Maulana Malik Ibrahim, Malang.

Akhmad, R., Tanjung, R. H., Poli, A. I., Ali, A., \& Kumoro, N. B. (2019). Ethnicity, Identity, And The Politics Of Space In Urban Society Of Jayapura City. Advances in Social Sciences Research Journal, 6(2), 383-399.

Akhmad A., Idris U., Siregar L. (2018). Mitos Sawerigading (Epos Lagaligo): Suatu Analisis Struktural dan Penafsiran. ETNOSIA: Jurnal Etnografi Indonesia, 3(2), 224249.

Al-Makassary R. (2017). Mengenal Kampung Enggros di Kota Jayapura. Laporan Penelitian Alpha I.

Berkes F. (Ed). (1989). Common property resources: ecology and community-based sustainable development. Belhaven Press. London.

Cowan H. K. J. (1953). Voorlopige resultaten van der ambulijk laalanderzoek in Nieuw-Guinea. s'Gravenhage : Martinus Nijkhoff.

Creswell J. W. (2012). Research Design Pendekatan Kualitatif, Kuantitatif, dan Mixed. Yigyakarta: Pustaka Pelajar.

Erari, K. P. (1999). Tanah Kita, Hidup Kita, Hubungan Manusia dan Tanah di Irian Jaya Sebagai Persoalan Teologis. Jakarta: Pustaka Sinar Harapan.

Frank S. A. K., Wenehen A., Idris U. (2020). The land tenure and the land use among supiori in Papua. ETNOSIA: Jurnal Etnografi Indonesia, 5(1), 105-118.

Feeny D. (1994). Frameworks for understanding resource management on the commons, p. 20-33. In R.S. Pomeroy (ed.) Community management and common property of coastal flsherles In Asla and the Paciflc: concepts, methods and experiences. ICLARM Conf Proc. 45. 189 p. 
Hijjang P. (2016). The Empowerment of The Local Knowledge In Handling and Tackling The Disasters in Sinjai Regency. IJMAS: International Journal of Management and Applied Science), Special Issue-1, 8(2): 98-101.

Hijjang P., Lampe M. (2017). The Farmers Local Knowledge To Support The Environment Friendly Agroecopreneur In South Sulawesi. Science International, 29(1), 169-169.

Hijjang P., Ismail A., Marhadi A., Frank S. A.K., Sokoy F., Idris U. (2018). Puyakhabhu: Local Wisdom Values In Environmental Management At Sentani Indigenous Community In Jayapura Regency, Papua. International Journal of Art E Sciences. 11(1), 59-65.

Idris U. (2017). Belimpun Taka Tugas, Insuai Taka Tapu': Orang Tidung,Marginalisasi dan Perlawanan di Pulau Sebatik, Nunukan. ETNOSIA: Jurnal Etnografi Indonesia, 2 (12), 134-152.

Jakarimilena N. 1993. Orang Tobati dan Enggros (Sebuah Etnografi). in Roembiak, Mientje De (eds). Etnografi Irian Jaya : Panduan Sosial Budaya, Buku Satu Kelompok Peneliti Etnografi, Irian Jaya. Uncen Press: Jayapura.

Kadir, A., Rahmanto, M. I., Idris, U., \& Ali, A. (2020, October). The process of economic change of the Papuans in Jayapura. In IOP Conference Series: Earth and Environmental Science (Vol. 575, No. 1, p. 012040). IOP Publishing.

Kadir, A. (2017). Melihat Indonesia dari Jendela Papua: Kebinekaan dalam Rajutan Budaya Melanesia. JSW (Jurnal Sosiologi Walisongo), 1(2), 225-246.

Karubaha J. J. (2007). Revitalisasi Nilai-nilai Keariifan Lngkungan dalam Pembangunan Berkelanjutan (Studi kasus Ekologi Pembangunan Masyarakat Adat Papua dan Iimplikasinya untuk Pemekaran Kesadaran Kesatuan Persatuan Nasional dan Pengembangan Ilmu Lingkungan sebagai Multidisiplin Ilmu). Disertasi, Universitas Indonesia.

Kusnadi. (2005). Keberdayaan Nelayan dan Dinamika Ekonomi Pesisir. Yogyakarta: ArRUZZ Media. [in Indonesian]

Liliweri A. (2014). Pengantar Studi Kebudayaan. Nusamedia, Bandung. [in Indonesian]

Lampe M. (2012). Pengelolaan Sumber Daya Laut Kawasan Terumbu Karang Takabonerate dan Paradigma Komunalisme Lingkungan Masyarakat Bajo Masa Lalu. Antropologi Indonesia, 33(3) : 216-227. [in Indonesian]

Lonthor A., Asba A. R., Hamdat S. (2016). Concept "Larvul Ngabal" Settings in Marine Resources Management in Southeast Maluku Kei Islands. International Journal of Scientific and Research Publications. 6(1): 524-530.

Mansoben J. R. (1994). Sistem Politik Tradisional di Irian Jaya. Jakarta, LIPI-RUI.

Naping H. (2017). Manusia, Laut, dan Kebudayaan. Yogyakarta, Kaubaka.

Purba J. (2002). Pengelolaan Lingkungan Sosial. Kantor Menteri Negara Lingkungan Hidup. Jakarta, Yayasan Obor Indonesia. [in Indonesian]

Purwanto H. (2010). Kebudayaan dan Lingkungan dalam Perspektif Antropologi. Yogyakarta: Pustaka Pelajar. [in Indonesian]

Taryono, Paulangan Y.P., Al-Amin M. A., Wahyudin Y. (2018). “Tiaitiki: Pengetahuan Lokal dan Lembaga Lokal untuk Mendukung Konservasi Laut di Teluk Depapre Provinsi Papua, Indonesia" dalam Adrianto L., Irianto O., Wardiatno Y., Fahrudin A., Taryono, Krisanti M., Hariyadi S., Mashar A. (ed). (2018). Bentang Laut Lesser Sunda dan Bismarck Solomon. Bogor: IPB Press, p 37-59. [in Indonesian]

Tebay S. (2013). “Pola Pemanfaatan Sumber Daya Perikanan oleh Masyarakat Teluk Yotefa". dalam Himayanti Y., Apriliani T., Zamroni A., Putri H. M. (ed). (2013). Prosiding Seminar Nasional Riset Sosial Ekonomi Perikanan Tahun 2013: Memperkuat implementasi Hasil Penelitian Sosial Ekonomi dalam Mendukung Percepatan Industrialisasi di Sektor Kelautan dan Perikanan Berbasis Blue Economy. Universitas Diponegoro, Semarang. 
Tebay S., Yulianda F., Fachrudin A., Muchsin I. (2015). Manjo Costumary Law in Fisheries Management System of Youtefa Bay, Papua. Australasian Journal of Social Science. 1(1), 34-41.

Wanggay R. (2011). Pengelolaan Sumberdaya Pesisir dan Laut Oleh Masyarakat Adat Tobati dan Enggros Di Kawasan Teluk Youtefa Kota Jayapura. Thesis, Universitas Gajah Mada, Yogyakarta. 